\title{
Endüstriyel İşletmelerde Franchising Model Önerisi: Hazır Beton Sektöründe Bir Uygulama
}

\author{
İpek KAZANÇOĞLU ${ }^{1}$
}

Özden ÖKTEM²

$\ddot{O} z$

Endüstriyel pazarda faaliyet gösteren firmaların daha hızlı büyüyerek, yeni pazarlara açılmasında franchising sistemi yeni bir satış, dağıtım kanalı olarak değerlendirilmektedir. Amaç, hazır beton sektöründe faaliyet gösteren bir firmanın franchising sistemini bir iş modeli olarak benimseme kararını almasında dikkat etmesi gereken unsurları ve karşılaşılan zorlukları incelemektir. Örnek olay çalışması olarak, yöneticilerle derinlemesine görüşme gerçekleştirilmiştir. Bu görüşmelerde amaç, firmanın franchising uygulamalarına ilişkin görüşlerini öğrenmektir. Görüşmeler sonucunda, franchising sisteminin hazır beton sektöründe bir model önerisi olarak uygulanıp/uygulanmayacă̆g değerlendirilmektir. Bulguların diğer endüstriyel işletmeler için de geliştirilebilecek bir franchising iş modeli kararında etkili olabileceğ $i$ düşünülmektedir. Çalışma sonuçlarının franchising modeline etki eden faktörlerin anlaşılması yönünden uygulamaya katkı să̆layacă̆ beklenmektedir.

Anahtar Kelimeler: Franchising, Endüstriyel Pazarlama, Hazır Beton Sektörü

JEL Sinıflandırma Kodları: M13, M31

\section{A Franchising Model Proposal In Industrial Business : An Application In Ready Mixed Concrete Industry}

\section{Abstract}

Franchising system is evaluated as a new sales and distribution channel for the firms operating in the industrial market providing them ways of faster development and entrance into new markets. The purpose of this research is to investigate the elements to be considered and the challenges faced, while adopting the franchising system as a business model for a firm operating in ready mix concrete industry. The study is designed as a case-study, in-depth interviews are carried out with seven managers. Consequently, franchising system is evaluated as whether if this proposal is applicable as a model. Findings of in-depth interviews are useful because they provide understanding regarding the factors affecting the decision on the development of franchising business model by other industrial businesses.

Keywords: Franchise, Industrial Marketing, Ready-Mix Concrete

JEL Classification Codes: M13, M31

\footnotetext{
1 Doç. Dr., Ege Üniversitesi, İktisadi ve İdari Bilimler Fakültesi, İşletme Bölümü, ipeksavasci@gmail.com

${ }^{2}$ Batıbeton Sanayii A.Ş. Urla Tesis Şefi, ozdenoktem@baticim.com.tr
} 


\section{İ. KAZANÇOĞLU. - Ö. ÖKTEM}

\section{GÍRIS}

Rekabetin artmasiyla birlikte her firma yeni bir pazarlama stratejisini incelemek ve uygulamak zorunda kalmıştır. Franchising sistemi, pazarını genişletmek isteyen işletmelerde büyüme hedeflerine ulaşmada kullanabilecekleri stratejik yöntemlerden biri iken, küçük firmalara büyük bir firmanın desteği ve güvencesiyle yatırım yapma olanağı sunmaktadır. Literatürde franchising üzerine perakendecilik ve hizmet işletmelerinde çok fazla çalışma yapıldığı, endüstriyel pazarlara yönelik ise sınırlı sayıda akademik çalışmanın yapılmış olduğu görülmektedir. Bu araştırma, franchising sistemini bir model olarak benimsemek isteyen endüstriyel bir firmanın bu kararında etkili olabilecek faktörlerin belirlenmesi için gerçekleştirilmiştir.

Ülkemizde, alanında yapılmış çalışmalar incelendiğinde, franchising uluslararası pazarlara açılmada bir büyüme modeli olarak ele alınmış (Aslanoğlu, 2007; Küçük, 2011), daha çok hizmet işletmelerinde perakendecilik sektöründe otel, hazır yemek (fast-food) (Görkem, 2015), kozmetik, giyim, bankacılık ve restoran zincirlerine yönelik gerçekleştirilmiştir (Ünüsan, 1998; Candan, 2000; Nart, 2005; Türksoy vd., 2013; Arıcan ve Zengin, 2015). Endüstriyel pazarda ise, franchising alanında yapılan çalışmaların sınırlı olduğu göz önünde bulundurulduğunda, bu çalışmanın literatüre ve bu alanda yatırım yapmak isteyen firmalara katkı sağlayacağı düşünülmektedir.

Çalışmanın birinci bölümünde franchising tanımı, avantaj ve dezavantajları ile dünyadaki ve Türkiye'deki franschising gelişimi incelenmiştir. İkinci bölümde, endüstriyel pazarlarda franchising uygulamaları ele alınmıştır. Üçüncü bölümde ise, franchising hazır beton sektöründe bir model önerisi olarak uygulanıp/uygulanmayacağı yönünden incelenmiş ve yapılan derinlemesine görüşmelerle değerlendirilmiştir.

\section{FRANCHISING TANIMI, KAPSAMI VE GELISŞIMI}

Literatürde franchising İngilizce olarak kullanılmakta ve köken itibariyle "Franchise" kelimesinden gelmekte olup kelimenin en yakın Türkçe karşıllı̆̆ 
"imtiyaz/ayrıcalık verme" olarak ifade edilmektedir. Franchising, tanınmış, kendi alanlarında başarılı olmuş; ürün veya hizmet üreten firmaların ürün veya hizmetinin ülke içinde ya da dışında ana firmaya benzer şekilde; benzer görünümlü mağazalarda üretilmesini, dağıtılmasını sağlayan bir pazarlama yöntemidir (Keegan ve Green, 2008: 296; Velentzas ve Broni, 2013: 764).

Ulusal Franchising Derneği (UFRAD)'ne göre franchising, “bir ürün veya hizmetin imtiyaz hakkına sahip tarafın, belirli bir süre koşul ve sınırlamalar dahilinde işin yönetim ve organizasyonuna ilişkin bilgi ve destek (know-how) sağlamak sureti ile, imtiyaz hakkını ticari işler yürütmek üzere ikinci tarafa verdiği imtiyazdan doğan, uzun dönemli ve sürekli iş ilişkilerinin bütünü” olarak tanımlanmıştır (UFRAD; Nart, 2005:124). Franchising, franchisor (franchise veren) ile franchise alan (franchisee) olarak adlandırılan, birbirinden hukuken bağımsız iki taraf arasında gerçekleştirilen sözleşmeli bir ilişkidir. Franchisor (Franchise veren), kendi alanında başarılı olmuş, belirli bir kalite standardında, tanınmış, bilinen bir markadaki ürün ve/veya hizmetin, işletme sisteminin sahibidir (Nart, 2005:124). Kullanım haklarını verdiği ürün veya hizmet ile ilgili bilgileri, organizasyon gereksinimlerini karşılayacak nitelikte bir planı, işletim sisteminin nasıl kullanılacağı hakkında rehberlik ve destek sağlamak zorundadır (Yan ve Wang, 2012: 1165). Franchisee, franchisor'a yıllık ciro ve kardan, anlaşmayla belirlenen oranlarda royalty adı altında belirlenen bir yüzde olarak lisans bedeli ödemek yükümlülüğündedir.

Günümüzde en iyi bilinen iş modeli olan franchising sisteminin gelişimine bakıldığında, hızlı gıda tüketim sektöründe genelde zincir organizasyonlar şeklinde karşımıza çıkmaktadır. Uluslararası Franchising Birliği (IFA) tarafindan hazırlanan raporda "farklı sektörlerde açılan 2015 yll franchising firmalarının işyeri sayısı, istihdam, üretilen çılktı, GSYIH içindeki oranları incelenmiştir. Rapora göre, otomotiv; taşımacllık, depolama, sigorta acenteleri, araştırma ve güvenlik hizmeti gibi iş hizmetleri; ticari ve konut hizmetleri; otel, hotel vb. konaklama; eğitim, ĕglence gibi kişisel hizmetler; hızlı gıda tüketim hizmeti (fast-food gibi); tam hizmet veren restoranlar; emlak; glda 


\section{İ. KAZANÇOĞLU. - Ö. ÖKTEM}

perakendecileri; mobilya, sağllk ve kişsisel bakım, kitap ve müzik mağazaları vb. perakendeci mağazaları gibi toplam 10 alt sektörün rakamları değerlendirilmiştir. Toplam çıktı miktarına göre, konaklama ve gayrimenkulde \% 6,3'lük büyüme yaşanırken; gıda perakendeciliğinde \% 3,9'luk bir büyüme görülmüştür. Ístihdam açısından, hızlı gıda tüketim hizmeti \%3,2'lik büyüme yaşarken, tam hizmet veren restoranlarda \% 2,4'lük büyüme yaşanmıştır. Açılan işyeri oranları incelendiğinde; kişisel hizmetlerde \%1,9'luk büyüme, gıda perakendeciliğinde \%1,1'lik bir büyüme sağlamıştır. 2015 yılı hızlı gıda tüketim hizmeti \%20’lik oranla gerek açılan işyeri dağılımına göre, gerek $\% 38 ' l i k$ oranla istihdam açısından, gerekse de \%26'lık oranla toplam çıktı miktarı açısından en büyük paya sahiptir. İkinci en büyük payı alan sektör kişisel hizmetler toplam açılan işyeri sayısı içinde \%15'lik oranla küçük işletmelerden oluşurken, istihdama \%8'lik, toplam çıktı miktarına ise \%11'lik katkı yapmaktadır. En küçük payları ise, işyeri açısından \%3'lük konaklama, $\% 4$ 'lük otomotiv işletmeleri almıştır. İstihdam açısından \%2'lik oranla otomotiv ve toplam çıktı miktarına göre, \%5'lik oranla otomotiv, gıda perakendeciliği almıştır. Işs hizmetleri sektörü ise, toplam içinde \%19'luk bir payla işyeri başına ve çalışan başına düşen çıtktı miktarı açısından en büyük ikinci sektör olduğu" belirlenmiştir (Franchise Business Economic Outlook, 2015).

Ülkemizde franchising sistemi 1985 yılında TURYAP ile başlamış, 1986'da Mc Donalds tarafından verilen ilk yabancı franchise ile birlikte sektör büyümeye başlamıştır. Ancak henüz istenen düzeyde geliştiğini söylemek zordur. Türkiye'ye fast food ile giren ve günümüzde gıda ve tekstil başta olmak üzere birçok hizmet sektöründe büyük bir pazar ağına sahip olan franchising, özellikle son yıllarda hızlı bir biçimde yaygınlaşmaya başlamıştır. Sektörde, 2015 y1lı itibariyle bin 850 civarında zincir işletme bulunuyorken, yüzde 24'ü yabanc1, yüzde 76's1 Türk kökenli marka zincirine bağlı şube sayısı ise, yaklaşık 50 bindir. Franchise zincir mağaza sayısıyla Avrupa birincisi olan Türkiye, sektörel kar marjını giderek arttırmaktadır. 2014 y1lı itibariyle franchising sektöründen 40 milyar dolarlık gelir ve 200 bin kişilik istihdam elde 
edilirken, 2016 y1lı için pazar beklentisi 50 milyar dolar olarak tahmin edilmektedir. Frachisor'un başarısı franchising verdiği firmaların başarısına bağlıdır. $\mathrm{Bu}$ anlamda, franchisee, önemli stratejik ve operasyonel destek satın alabileceği firmayı seçecektir (Velentzasa ve Broni, 2013: 1165). Franchising sisteminin uygulanabilmesi için iyi oturmuş bir kurum kimliği ve iyi bilinen bir marka isminin var olması gerekmektedir. Türkiye'de bu tanıma uygun firma sayısının azlığı göze çarpmakta ve sahip olanların ise, bilgi birikimlerini paylaşmaktan çekindikleri gözlenmektedir. Ayrıca franchise veren ve alan arasındaki ilişki kalitesinin yeterince sağlanamaması, sistemin ülkemizde gelişememesinin en büyük nedenlerindedir. Sistemin ülkemizde gelişememesinde etken SPK'ya kayıtlı olan firmalar dışında bağımsız denetim kavramının oluşmamış olmasıdır (Nart, 2005:127). Franchising sisteminin muhasebe kayıtları üzerinden işlemesi, kayıt dışı ekonominin önüne geçilmesinde önemli bir etkendir.

\section{FRANCHISING SISTEMININ TARAFLARA SAĞLADIĞI AVANTAJ VE DEZAVANTAJLAR}

Franchising sisteminde tarafların karşılaşabileceği zorluklar incelendiğinde; franchisor tarafinda marka değerinin korunup korunmayacağı, verilen işletme modelinin istenildiği şekilde uygulanıp uygulanmayacağı, franchisee tarafında ise hem işletme sermayesi, hem de ödenecek franchising bedelinin firmaya getireceği yük ve her iki taraf açısından hukuki olarak bir sorun oluştuğunda nasıl çözülebileceği ilişkin konulardır. Wang vd. (2006) çalışmasında franchising modelinin düşük maliyet avantajı kazanmaya ve tedarik zincirini bilgi kanalları ile tedarikçileri bağlamada etkili olacağını belirtmiştir. Bundan dolayı tedarik zincirinin yüksek seviyede ilişkisine bağlı olarak üretim, ürün kalitesi, stok seviyesi ve taşıma kapasitesi gibi değişkenlerin kolayca takip edilmesi sağlanacaktır (Yan ve Wang, 2012: 1165). Saleh ve Kleiner (2005) franchising modelinin yeni pazara girişte ve faaliyetleri büyütmede işletmeler için başarılı bir strateji olduğunu belirtmiştir. Rubin (1978) çalışmasında franchise veren firmanın satılan ürünlerin, fiyat, çalışma saatlerinin, fabrika 


\section{İ. KAZANÇOĞLU. - Ö. ÖKTEM}

koşullarının, sigorta, stokların, çalışanların, muhasebe ve denetim konularını kontrol edebildiğini ifade etmiştir.

Franchise veren açısından avantajlar; firma pazar payını maliyetsiz, hızlı bir şekilde büyütebilmekte; sermayenin daha iyi geri dönüşünü sağlayabilmekte; farklı bölgelerde çok rahat etkinliklerini sürdürebilmekte; düşük sermaye ve işgücü ile büyük firmalarla rekabette daha güçlü duruma geçebilmektedir. Dağıtım ağında hızlı genişleme ile firmanın adını ve ününü arttırabilmektedir (Küçük, 2011: 22; Velentzas ve Broni, 2013: 766).

Franchise veren açısından dezavantajları; franchisee seçimi zordur, zincirde yer alan franchise alanların aynı standardizasyonu sağlayamaması ve yanlış personel seçimi markaya olumsuz yansıyabilmektedir (Küçük, 2011: 23). $\mathrm{Bu}$ sebeple franchise veren firmanın franchise alan firma üzerindeki kontrolü ve tedarikçilerinin denetimi konuları çok önemlidir. Franchise alan firma yeterli sermayeye sahip ve işi benimseyecek yapıda olmalıdır. Aksi takdirde, firma markaya zarar verebilmekte, işi yürütemediğinde o bölgedeki pazar payına olumsuz yansımalar yaratabilmektedir. Franchise alan firma işi öğrendikten sonra, aynı işletme yöntemleriyle ana firmaya rakip olabilmektedir. Bu konuda iyi bir sözleşme yapılması kesinlikle şarttır (Salar ve Salar, 2014; Ulaş, 2015).

Franchisee açısından avantajları: Başarısı kanıtlanmış, tanınmış bir marka ile birlikte, ulusal veya uluslararası standarda kaliteye sahip olacak ve tanınmış markalara sürekli müşteri ve iş yapma imkanı sağlayacak, satmak çok daha kolay olacaktır. Belirli ve hazır bir müşteri potansiyeli olan bir marka ile franchise anlaşması yapmak, franchise alan açısından daima daha kolay satış yapmak anlamına gelmektedir. Franchise veren işletme franchisee'ye eğitim hizmetleri ve uzman personel, mali, ticari ve personel konularında desteklemekte, teknik uzmanlık bilgisini kullanarak, teknik işlevlere verip, franchisee'nin başarı şansını arttırılabilmektedir (Cebeci, 2005: 9). Franchisor ile ortak hareket ederek küçük işletmeler kendileri yeni bir işletme kurmak yerine, daha az sermayeye ihtiyaç duyarak, riskleri ve işletmecilik sorunlarını 
minimize edeceklerdir. Franchisor'un sürekli olarak yaptığ 1 araştırma ve geliştirme çalışmalarından, kaliteli personel bulma, işe alma ve yerleştirme konularında, mali ve hukuk danışmanlarından yararlanabilecektir. İşletmenin kuruluş aşamasında ve kuruluş yerinin seçiminde bilimsel tekniklerin kullanılması, kuruluş aşamasında leasing gibi kaynaklardan yararlanması ve finansal konularda kredi standardını arttırması gibi konularda avantaj; reklam ve tanıtım giderlerinden tasarruf sağlayacaktır (Cebeci, 2005: 9). Franchisor'un daha büyük miktarlarda malzeme, hammadde, yarı mamul ve mamul satın sonucu franchise daha iyi fiyatla satın aşma yapacak ve firmaların karlılı̆̆ına olumlu etki edecektir. Piyasada hakim olan firmalarla daha kolay rekabet şansına sahip olmaktadırlar (Salar ve Salar, 2014; Ulaş, 2015).

Franchisee açısından dezavantajları: Franchising sistemine katılmak için ödenmesi gereken başlangıç bedeli genellikle yüksektir. Bu başlangıç ücretleri; marka değerinin peşin alınması, gerekli yatırım amaçlı tüm ekipman, malzemelerin temini, eğitim masraflarından oluşmaktadır. Sözleşmede; gerekli malzeme ve ekipman, ana firmanın belirlediği mağazalardan alınmakta ya da ana firma tarafindan temin edilmektedir. Franchisee kendi bölgesel tedarikçisinden daha ucuza satın alabileceği malzemeleri bile ana firmanın belirlediği yerlerden satın almak zorundadır. Genellikle kar da taraflar arasında paylaşılmaktadır. Franchise alan, sisteme giriş ücretinden başka sürekli olarak, aylık satışların belirli bir yüzdesini yani royalty bedelini (\%1-\%11) ana firmaya ödemek zorundadır. Royalty'nin çok yüksek istenmesi franchise alanların işletmelerini kapatmak zorunda kalmalarına neden olabilmektedir (Cebeci, 2005: 10). Franchisee'nin hukuken bağımsız bir işletmeci olmasına rağmen, ana firma tarafından ticari faaliyet performansına yönelik çeşitli işletme bilgileri ve mali tabloları devamlı takip edilmekte, sürekli denetlenerek kontrol edilmektedir. $\mathrm{Bu}$ anlamda, franchisor firmasına bağımlıdır. Franchisee, standardizasyonun bozulmaması için kendi bölgelerinde sattıkları ürünlerin içeriğinde değişiklik yapamamaktadır. Kendi birimine yakın bir yerde, yeni bir franchise biriminin açılması sonucu franchisor'la aralarında çatışma 


\section{İ. KAZANÇOĞLU. - Ö. ÖKTEM}

doğabilmektedir (Cebeci, 2005: 10). Franchise alan diğer firmalardan birinde oluşan bir itibar kaybı, tüm franchise alan firmaları etkileyebilmektedir (Salar ve Salar, 2014; Ulaş, 2015).

\section{ENDÜSTRIYYEL PAZARLARDA FRANCHISING}

\section{UYGULAMALARI}

Endüstriyel pazar, diğer firmalara satılan, kiralanan veya tedarik edilen, diğer ürün ve hizmetlerin üretiminde kullanılmak için, ürün ve hizmetleri satın alan organizasyonları içeren pazar olarak tanımlanmaktadır (Tosun ve Emirza, 2014: 273). Endüstriyel pazarlarda dağıtım kanalı yapısı incelendiğinde, franchising sisteminin çok yaygın olduğu görülmemektedir. Örnek olarak İtalya'da 562 franchise veren firma arasindan sadece 6 adet firma (\%1) endüstriyel franchise sistemi uygulamaktadır. Çok yaygın olmamakla birlikte endüstriyel franchise uygulamaları, B2B tedarik zincirinin özel bir uygulaması, genellikle bir franchise veren ve birden fazla franchise alandan oluşmaktadır. Endüstriyel franchise uygulamaları bilgi ve teknoloji transferi, internet üzerinden gerçekleşen bir ağ ile tedarik zincirinin ortak kullanılması gibi konularında gelişmektedir. Franchising sisteminde bilgi paylaşım modeli, franchior ve franchisee arasında talep tahmin bilgisinin paylaşılmasıyla, fiyatlama stratejileri, envanter ve ikmale yönelik tasarruf sağlamaktadır (Yan ve Wang, 2012: 1165). Perakendecilik alanındaki franchising uygulamalarına göre, endüstriyel pazarda franchisee firması franchisor tarafından çok daha fazla satış desteği beklemektedir. Bu şekilde franchising, firmalar arasında maliyetleri düşürmek ve verimliliği arttırmak açısından geniş çeşitlilikteki endüstriler ve çeşitli seviyelerdeki operasyonlar için rekabet avantaj1 sağlayan büyük bir potansiyele sahiptir. B2B pazarında bir grup tedarikçinin diğer bir grup satıcıyla temasa geçmesiyle, geleneksel sipariş sistemini ortadan kaldırmayı başarmıştır. İnternet tabanlı platformda ürünleri veya hizmetleri almak veya satmak için firmalar arasındaki işbirliğini sağlamaktadır (Sherman, 2001:1). 


\section{HAZIR BETON SEKTÖRÜNDE FRANCHISING}

\section{UYGULAMALARI}

İnşaat sektörünün en temel kollarından birini oluşturan hazır beton sektörü, diğer ülkelere göre Türkiye'de oldukça genç bir sektör olmasına rağmen, 2014 y1lında Avrupa'nın en büyük üreticisi iken, dünyada en büyük 3. üretici konuma gelmiştir. Toplam cirosu 5 milyar USD'a ulaşmıştır. Son 5 yılda \%34'lük bir büyüme gerçekleştirmiştir (Hazır Beton İstatistikleri, 2014). 2013 y1lında Türkiye'de Hazır Beton Birliği'ne kayıtlı hazır beton firma sayısı 580'dir, toplam tesis sayıs1 1040'dır (Hazır Beton İstatistikleri, 2014). Ülkemizdeki artan nüfus artışı ve bunun getirdiği konut ihtiyacıyla birlikte kamu kaynaklı projeler, 3. havaalanı inşaat1, 3. köprü, Avrasya Tüneli, İstanbul-İzmir Otoyol projesi gibi büyük projelerin varlığı, kamu hastaneleri ve kentsel dönüşüm projeleri hazır betona olan ihtiyacı arttırmaktadır. Türkiye'deki hazır beton sektörünün yaşadığı en önemli sorun, standart dışı-kalitesiz üretim ve faturasız satışlarla sektörde haksız rekabete ve tüketicinin mağduriyetine yol açan bazı hazır beton üreticilerinin olmasıdır. İnşaat sektörünün performansına bağlı gelişen hazır beton sektöründe 2015 yılında ERMCO (Avrupa Hazır Beton Birliği) tarafından yayınlanan "2014 Hazır Beton İstatistikleri” raporuna göre, hazır betonun dağıtım yöntemi incelendiğinde; \%70 firma üzerinden, \% 29 taşeron, \%1 müşteri üzerinden gerçekleştiği tespit edilmiştir (Hazır Beton İstatistikleri, 2014). 2012 y1lı verilerine göre, coğrafik bölgeler bazında hazır beton üretiminde Ege Bölgesi \%10'luk bir paya sahiptir.

Türkiye'de hazır beton sektöründe franchising modelini benimseyen firmalar incelendiğinde; Lafarge Türkiye Agrega ve Beton Grubu, 2003 y1lında “franchise” yöntemiyle Sakarya'daki İnci Beton ve Ereğli'deki Balcı Beton ile tesis işletmiştir. Türkiye'nin 3. en büyük çimento üreticisi olan Limak Çimento Grubu'da hazır betonda franchising modelini 2013 yılında Çebitaş Beton Bandırma ve Susurluk tesislerinde uygulamaya başlatmıştır.

Endüstriyel pazarlarda franchising iş modeli çok fazla yer almamakla birlikte, literatürde hazır beton sektöründe çok fazla uygulama yapılmamıştır. 


\section{İ. KAZANÇOĞLU. - Ö. ÖKTEM}

Johnson (2010), franchising modelini perakendeci olmayan firmalar için yenilikçi olarak tanımlamış, franchise veren çimento tedarikçilerini düşünerek, hazır beton sektöründe pazarı genişletmek için bir araç olduğunu, maliyetin en önemli rekabetsel faktör olduğunu belirtmiştir. $\mathrm{Bu}$ anlamda hazır beton sektöründe de, büyük çimento üreticisi firmalar franchisor konumda iken, küçük hazır beton sağlayıcıları franchisee konumundadır. Bu konuda, Sirichalermpong vd. (2012) ile Sirichalermpong ve Chansa-ngavej (2012 a,b) Tayland'da büyüyen bir pazar haline gelen hazır beton sektöründe franchising uygulamalarını çalışmalarında incelemişlerdir. Tayland Sanayii Bakanlığı verilerine göre, 2012 yılında Tayland'da 1000'den fazla hazır beton üretimi yapan firma bulunmaktadır. Bu hazır beton firmaları iki grupta toplanmıştır. Bunlardan ilk grup, çimento üretimi yapan firmaların sahip oldukları hazır beton tesisleri; ikinci grup ise, çimento ihtiyaçlarını ilk gruptaki firmalardan tedarik eden bağımsız hazır beton üreticileridir. Özellikle ikinci gruptaki firmaların pazarda çok fazla olması nedeniyle, arz fazlası oluşmuş ve fazla üretici tarafından pazar bölünmüştür. Bu aşamada pazar payını ve piyasadaki rekabet gücünü arttırmak amacındaki çimento üreticileri de yeni bir strateji geliştirmişlerdir. Hazır betonda franchising modeli ilk olarak Tayland'daki lider hazır beton üreticisi CPAC tarafından 2000 yılında geliştirmiş olduğu bu sistem 2010 yılına gelindiğinde 140 adet franchise alan firmaya ulaşmıştır. Ülkedeki 2. en büyük hazır beton üreticisi olan INSEE firması 2006 yılında mevcut çimento satış kanalını elinde tutmak amacıyla az sermaye ile daha fazla hazır beton pazar payına ulaşabilmek için bu sisteme geçmiştir. 2010 yılında INSEE firması 60 adet franchise alan firmaya sahip olmuştur. Bu sistem ile her iki firma artan franchise sayısı ve büyüyen pazar payları ile başarılı bir franchise sistemi oluşturduklarını kanıtlamışlardır.

Sirichalermpong ve Chansangavej (2012b) çalışmasında hazır beton sektöründe franchise alan firmaya sağladığı algılanan faydalar incelendiğinde; imaj ve itibarı yükselterek, yüksek üretim kalitesi ile daha yüksek bir satış hacmine ulaşma; daha büyük projelere, devlet projelerine hazır beton 
sağlayabilme olanağı; ulusal ve uluslararası müteahhitlere ulaşma imkanı sağlama; mal satın alırken bağlantılar oluşturması, örneğin daha iyi fiyattan, franchise veren firmanın ikinci el makinelerinden yararlanmak, alternatif tedarikçilere ulaşmaktır.

Hazır betonda franchise veren tarafa verilen destekler, ortağın rekabet gücünü ve tedarik zincirini geliştirerek arttıracaktır. Bu destekler; ticari destek olarak ticari eğitim, tedarik zincirinin geliştirilmesi, iş ve kalite geliştirme koçluğu vb.; teknik destek olarak teknik bilgi transferi; tedarikçi desteği, franchise alan firmanın memnuniyet seviyesi, değer sunumu, müşteri ilişkilerinin oluşturulması vb.; problem, iş ve teknik çözüm danışmanlığıdır (Sirichalermpong ve Chansangavej, 2012b: 49).

Sirichalermpong ve Chansangavej (2012a) çalışmalarında franchise almak isteyen firmalara anket çalışması yaparak hazır beton sektöründe franchising sisteminin bir iş modeli olarak tercih edilmesi için itme ve çekme olarak iki faktörün etkili olduğunu ortaya koymuştur. Hazır beton sektöründe hayatta kalabilmek için belirsiz çevre koşullarında rekabetçi olmak gerekmektedir. Sektörde franchise alan için potansiyel rekabet şansını geliştirmek ve büyütmek için en iyi çözüm, piyasadaki en iyi ortağı bulmaktır. Bu sektörde franchising ağına katılma kararını etkileyen faktörler itme ve çekme faktörlerdir. Çevresel belirsizlikler olarak ekonomik koşullar, çevresel endişe, pazar koşulları, teknolojik değişimler itme faktörleri olarak tanımlanır ki bunlar bağımsız hazır betoncuları, kendilerini geliştirecek ve büyütecek iyi bir iş ortağı bulmaya yöneltmektedir (Sirichalermpong ve Chansa-ngavej, 2012a: 237). İtme faktörü kontrol edilemeyen bir faktör olarak işletmenin bu şekilde bir işletme modeli oluşturmasına negatif etki etmektedir. Bunlar; ekonomik koşullar - ekonomik kriz baskısı, enflasyon oranı, faiz oranı, petrol fiyatı v.b; çevresel durumlar çevresel yasal düzenlemeler, küresel ısınma endişesi, çevresel konularda toplumsal bask1; piyasa şartları - piyasa talebindeki dalgalanmalar; fiyat duyarlılığı; yüksek rekabet seviyesi, özel ihtiyaç ve istekler v.b'dir. Ayrıca, teknolojik değişimler - yapı teknolojisindeki değişiklikler, hazır beton 


\section{İ. KAZANÇOĞLU. - Ö. ÖKTEM}

teknolojisindeki değişimler, taşımacılık teknolojisindeki değişiklikler, yeni ürün inovasyonları vb. şeklinde sıralanmaktadır.

Çekme faktörler ise, kontrol edilebilen faktörler olarak olumlu etki yaratarak, franchise alan adayın franchise ağına katılması için teşvik eden pozitif faktörlerdir. Bunlar; iş geliştirme desteği- satış kanallarına giriş, kolay kredi, hammadde tedarikçilerine erişim, araç taşeronlarına erişim gibi; satış fırsatını arttırma-iyi bir markanın kullanım hakkını elde etme, büyük projelerde görev alma firsatı yakalama; teknik ve operasyonel destek - tesis kuruluş ve operasyonel desteği, iş süreçleri desteği, kamyon filosunu yönetme vb.; ürünle ilgili - ürün kalite geliştirme, ürün çeşitliliği, ürün inovasyonu vb.; ilişki ve ağ bağlantıları - franchise ağına katılma, franshise veren ile ilgili ilişkilerin geliştirilmesi, danışmanlık, tedarik zinciri ilişki ağı gibi sıralanmaktadır (Sirichalermpong ve Chansa-ngavej, 2012a : 237). Çekme faktörleri arasında satış fırsatlarının arttırılması, teknik/operasyonel destek, ürünle ilişkili bağlantılar anlamında yüksek değer yaratmıştır. Ayrıca, itme faktörleri arasında teknolojik değişim ve pazar koşullarının, ekonomik koşullara ve çevresel endişelere göre daha etkili olduğu belirlenmiştir. Franchising iş modeli, hazır beton sektöründeki dikey entegrasyon yoluyla kendi yatırımlarıyla karşılaştırıldığında firmanın pazar payını büyütmekte, pazardaki bağımsız hazır beton üreticilerini franchising ağı içerisine alarak birleştirerek, pazardaki yapıyı güçlendirmekte ve düşük sermaye yatırımları ile güvenli çimento kanalı oluşturarak daha hızlı büyüme sağlamaktadır. Sirichalermpong ve Chansangavej (2012a) yaptıkları çalışmanın sonucunda çekme faktörünün, franchising veren firmanın kendi kontrolü altında olduğu için, itme faktörüne göre karar verme sürecinde çok daha etkili olduğu tespit edilmiştir.

Sirichalermpong vd. (2012), franchisor firmasının bakış açısıyla çimento üreten firmaların yöneticileri ile görüşmeler yaparak, franchise veren firmanın bir pazara kendi hazır beton tesisi ile girip girmeyeceği veya ilgili bölgede franchise vermesi ya da o bölgeyi bağımsız hazır beton firmasına bırakması konusunu etkileyen iki temel faktör olduğunu ortaya çıkmıştır. Bu faktörler; 
pazarın çekiciliği ve pazarın gelişmişliğidir. Bu faktörler yoluyla, franchising iş modelini benimseyip/benimsememe kararını verecektir. Bunlar;

1. Pazarın çekiciliği: pazardaki arz ve talebin denge durumu pazarın çekiciliğini belirlemektedir. Buna göre, pazardaki talep yüksek olsa bile, arz talebe göre çok fazla ise, bölgede talebe göre çok fazla bağımsız hazır beton tesisi var ise, bu pazarın çekiciliği düşüktür denilmektedir.

2. Pazarın gelişmişliği: Pazar gelişmişliğinden bahsedebileceğimiz bölgeler büyük projelerin olduğu; daha yüksek binaların ve mega projelerin olduğu, bu işler için zamanında sevkiyat garantisinin verildiği, daha yüksek teknik kapasiteli tesisler ve sevkiyat ağlarının gerektirdiği bölgelerdir.

Bu iki faktörün iki seviyesi (düşük-yüksek) Şekil 1'de pazarda dört olası kombinasyon yaratmaktadır. Bu kombinasyonlar incelendiğinde;

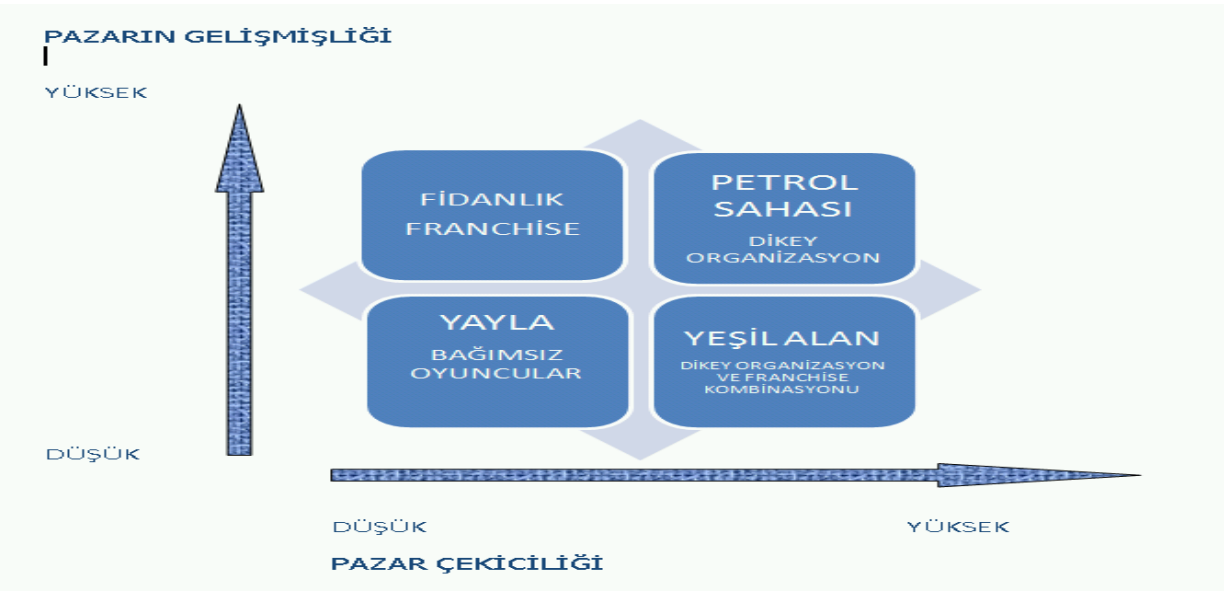

Şekil 1. Hazır Beton Sektörü için Pazar Genişleme Strateji Matrisi

Kaynak: Sirichalermpong ve Chansangavej, 2012a.

Petrol sahası (Oil Well): Bu alanda pazarın gelişmişliği ve pazarın çekiciliği yüksek olup, genellikle çok gelişmiş şehir merkezleri bu sahayı oluşturmaktadır. Bu bölgelerde önerilen çimento üreticilerinin kendi tesislerini kurmalarıdır. Kendi güçlü yatırım ağlarıyla bu bölgelerde çok daha yüksek satış ağına ulaşabilecekleri gibi, ufak ve orta çaplı firmaların pazara girişleri için daha güçlü bir engel oluşturabilecektir. Bölgedeki projelerin ihtiyaçları 


\section{İ. KAZANÇOĞLU. - Ö. ÖKTEM}

incelendiğinde; özel bir karışım, garantili teslimat, tam zamanlı teslimat, şantiyede tesis kurulması, yüksek kaliteli ürünler ve hizmetler, markalaşma (yada itibar), yüksek bina teknolojisi talep etmeleridir.

Yeşil alan (Green Field) : Bu alan yüksek pazar çekiciliğine fakat düşük pazar gelişmişliğine sahip alanlardır. Bu pazarlar çok fazla karmaşık olmayan, konut projeleri, az katlı ticari binalar gibi birçok projeyle cazibe kazanmaktadırlar. $\mathrm{Bu}$ bölgelerde firma dikey organizasyon oluşturup kendi hazır beton tesisini kurabileceği gibi bazı bölgelerde franchise da verebilir ve bu durum yerel şartlara, arazi kısıtlamalarına, çevresel yönetmeliklere, bölgedeki ilişkilere ve bağlantılara, tedarik zincirinin verimliliğine, çevresel endişelere vs. gibi durumlara bağlıdır.

Fidanlık (Plantation): Pazar gelişmişliğinin yüksek, pazar çekiciliğinin düşük olduğu alanlardır. Toplam pazarın büyüklüğünün çok geniş olmaması, çimento üretici firmaları tarafından kendi yatırımını yapmayı düşündürmektedir. $\mathrm{Bu}$ alanlarda pazar gelişmişliği yüksek olmasına rağmen, talebe göre çok daha fazla üreticinin olması durumu vardır. Bu tarz pazarlarda, franchising olası bir stratejik seçenek olmaktadır, çünkü bu pazarlar genelde çok fazla oyuncuyla paylaşmaya değecek bir pazar değildir ve çimento üreticileri için marka bilinirliği olmayan bağımsız hazır beton üreticilerinin franchise alan firmalar olması çok daha önemlidir.

Yayla (Plateau): Pazar gelişmişliğinin ve pazar çekiciliğinin düşük olduğu bölgelerdir. Bu bölgelerde sanayi gelişmemiş olup, tarım ana endüstridir ve düşük bir hazır beton talebi mevcuttur. Bölgedeki inşaat projeleri ufak ve orta ölçekteki bina, yol, çiftlik betonları gibi projelerdir. Genel olarak gelişmemiş bölgelerdir ve bu bölgeleri bağımsız hazır beton firmalarına bırakmak en doğrusudur. Çimento üreticileri çimentonun satış hacminden marj almaktadırlar (Sirichalermpong vd., 2012:286-287). Hazır beton sektörü arz fazlası olan ve parçalı bir yapısı olduğu için franschising iş modeli rakipleri ortak hale dönüştürerek, sayıyı azaltmakta ve ağ yapısını güçlendirmektedir. 


\section{ENDÜSTRIYYEL İŞLETMELERDE FRANCHISIING BİR MODEL ÖNERİSI - HAZIR BETON SEKTÖRÜNDE UYGULAMA}

\subsection{Araştırmanın Amacı ve Kapsamı}

Araştırmanın amacı, endüstriyel pazarda faaliyet gösteren firmaların daha hızlı büyüyerek, yeni pazarlara açılmasında franchising sistemini yeni bir satış kanalı olarak değerlendirilip/değerlendirilmeyeceğini ve bu sistemde etkili olan faktörleri incelemek ve bu doğrultuda bir model önerisi geliştirmektir. Bu kapsamda araştırma Ege Bölgesinde en büyük hazır beton firmaları arasında yer alan BATIBETON A.Ş. firmasında yapılmıştır. BATIBETON A.Ş. firması grup şirketlerinden olduğu BATI ANADOLU Grubu'nun ilk çimento fabrikası olan BATIÇİM Batı Anadolu Çimento Sanayii A.Ş. 1966 yılında ve yüzde yüz Türk sermayesi ile kurulmuş ve bugüne kadar bölgede çimento üretimi konusunda lider bir firma olmuştur. BATIÇİM, 1986 yılında inşaat sektörünün artan beton ihtiyacının karşılanması BATIBETON markasını sektörün hizmetine sunmuştur. 1986 yılında İzmir Bornova'da hazır beton üretimine başlayan şirket, İzmir, Manisa, Aydın, Denizli ili ve ilçelerinde 18 hazır beton tesisi, 21 hazır beton santralı ile üretim yapabilmektedir. BATIBETON A.Ş. firmasının dağıtım kanalı yapısı açısından Ege Bölgesinde 42 adet bayi ile inşaat firmalarına hizmet vermektedir. Hazır beton sektöründe bulunduğu pazar itibariyle Ege Bölgesi içerisinde İzmir-Manisa-Aydın ve Denizli illerinde 50’ye yakın firma faaliyet göstermektedir. Ürün ve hizmet kalitesi ile birlikte müşteri memnuniyetini hedefleyen firma, çevreye olan duyarlılığı ve iş sağlığı güvenliği konusunda hassasiyeti ile sürekli yatırım yapmaktadır. BATIBETON A.Ş., tüm çalışanların katılımı ile toplam kalitenin artacağı bilincinde olup çalışanlara sürekli iç ve dış eğitimler verdirmektedir.

\subsection{Araştırma Yöntemi}

Araştırma amacı itibariyle keşfedici niteliktedir. Araştırmada nitel araştırma yöntemlerinden "görüşme tekniği" kullanılmıştır. Görüşme türleri arasında ise, 


\section{İ. KAZANÇOĞLU. - Ö. ÖKTEM}

karar problemi hakkında bilgi sahibi bireylerin verdikleri bilgiler arasında paralelliği ve farkl1lığı saptamak, buna göre karşılaştırmalar yapmak amacıyla "yapılandırılmış görüşme tekniğinden" yararlanılmıştır (Yıldırım ve Şimşek, 2008: 120). Görüşmelerde yararlanılan soru formunda toplam 16 soru yer almaktadır. Görüşmeler BATIBETON A.Ş. firması içerisindeki değişik kademelerdeki 7 yönetici (1 müdür, 6 şef düzeyinde) ile 2015 yılı Kasım ayından görüşme gerçekleştirilmiştir. Her görüşme yaklaşık 60 dakikalık bir süre içerisinde gerçekleştirilmiş olup, bilgilerin kaybolmaması için görüşmeler katılımcıların izniyle kaydedilmiştir.

\subsection{Araştırma soruları:}

- Franchising sisteminin hazır beton sektöründe uygulanabilir olup/olmadiğı?

- Hazır beton sektöründe franchising sistemi nasıl uygulanmalıdır?

- Hazır beton sektöründe franchising modeli uygulandığında olumlu yanları nelerdir?

- Hazır beton sektöründe franchising veren firmanın bu süreçte karşılaşabilecekleri zorluklar nelerdir?

- Franchising sistemi kurulurken taraflar arasında nasıl bir sözleşme yapilmalıdır?

- Franchising sisteminin hazır beton sektöründe sağlıklı bir şekilde işleyebilmesi için nasıl bir destek ve denetim mekanizması oluşturulmalıdır?

$\mathrm{Bu}$ araştırma soruları oluşturulurken; Combs vd. (2004), Aslanoğlu (2007), Sirichalermpong vd. (2012), Sirichalermpong ve Chansa-ngavej (2012 a,b) ile Velentzasa ve Broni (2013) çalışmalarından yararlanılmıştır.

\subsection{Araştırma Modeli}

Araştırma modeli olarak örnek olay çalışması tasarımı kullanılmıştır. Örnek olay incelemesi bir olgunun gerçek yaşam koşullarında derinlemesine 
incelenmesine dayanmaktadır. Araştırma sürecinde araştırma konusuna ilişkin keşfin yapılabilmesi için "nasıl”, "niçin” soruları yöneltilmektedir (Yin, 2002). $\mathrm{Bu}$ bağlamda, BATIBETON A.Ş. firması örnek olay şeklinde incelenerek, endüstriyel pazarda yapılması düşünülen franchising iş modelinin uygulanıp/uygulanamayacağı, başarısında etki eden unsurlar değerlendirilmiştir.

\subsection{Araştırmanın Geçerlilik ve Güvenilirliği}

Çalışmanın geçerliliğini arttırmak için görüşmeden elde edilen veriler ayrıntılı olarak rapor edilmiş, araştırma sonuçlarına nasıl ulaşıldığı açıklanmıştır. $\mathrm{Bu}$ kapsamda, betimsel analiz kullanılarak sonuçlar yorumlanmıştır. Araştırmanın iç geçerliliği için elde edilen bulguların anlamlı bir bütün oluşturması sağlanmış, bulguların kendi arasında tutarlı ve anlamlı olmasına dikkat edilmiştir. Araştırmanın dış geçerliliği ise, araştırma sonuçlarının araştırma soruları ile tutarlı olmasına çalışılmıştır.

Çalışmanın güvenirliği sağlamak amacıyla, üye kontrolü yöntemi izlenmiş; diğer bir ifadeyle çalışmaya katılan kişilere görüşme notları verilerek, görüşme kayıtlarının yanlışsız ve eksiksiz olduğu doğrulatılmıştır. Dış güvenirliği sağlamak amacıyla ise, verilerin analizinde kullanılan kavramsal çerçeve ve varsayımlar tanımlanmış; veri toplama ve analiz yöntemleri ile ilgili ayrıntılı açıklamalar yapılmıştır.

\subsection{Araştırma Verilerinin Analizi}

Görüşmeler sonucu elde edilen verilerin analizinde, betimsel analiz yöntemi kullanılmıştır. $\mathrm{Bu}$ analiz yönteminde, araştırma sorularının ortaya koyduğu temalara göre düzenleme yapılacağı için görüşme sürecinde kullanılan sorular dikkate alınarak değerlendirilmiştir. Bu kapsamda öncelikle;

- Betimsel analiz için araştırma soruları temel alınarak bir çerçeve oluşturulmuştur.

- Tematik çerçeveye göre veriler işlenmiştir.

- Bulguların tanımlanması amacıyla gerekli yerlerde görüşmelerden doğrudan alıntılarla desteklenmiştir. 


\section{İ. KAZANÇOĞLU. - Ö. ÖKTEM}

- Bulguların yorumlanması yapılmıştır (Yıldırım ve Şimşek, 2008:224).

\subsection{Araştırma Bulguları}

Görüşme yapılan katılımcılara ilişkin demografik bilgiler Tablo l'de sunulmaktadır. Görüşmelerde kurum içinde 15-25 yıldır çalışan deneyimli olarak nitelendirilebilecek personelin ağırlıklı olduğu görülmektedir. Deneyimli personelin hazır beton sektöründe franschising modelinin uygulanabilirliğine ilişkin bakış açıları da değerlendirilmiştir.

Tablo 1. Katılımcılara İlişkin Demografik Bilgiler

\begin{tabular}{|c|c|c|}
\hline \multirow{2}{*}{ CINSIYYET } & KADIN & 0 \\
\hline & ERKEK & 7 \\
\hline \multirow{2}{*}{ YAŞ } & $30-40$ & 3 \\
\hline & $40-50$ & 4 \\
\hline \multirow{5}{*}{ KURUMDA ÇALIŞMA SÜRESİ } & $1-5$ YIL & - \\
\hline & $5-10 \mathrm{YIL}$ & 1 \\
\hline & 10-15 YIL & 2 \\
\hline & 15-20 YIL & 3 \\
\hline & 20-25 YIL & 1 \\
\hline \multirow{3}{*}{ POZÍSYON } & YETKİLİ/UZMAN & 1 \\
\hline & ŞEF & 5 \\
\hline & MÜDÜR & 1 \\
\hline
\end{tabular}

Araştırmada öncelikle franchising sisteminin hazır beton sektöründe uygulanabilir olup/olmadığı sorulmuştur. Görüşme yapılan kişilerin franchising modelinin hazırbeton sektöründe uygulanabilirliği konunda bazı çekinceleri olduğu tespit edilmiştir. Buna göre, sektörde üretim ve kalite açısından çok kritik bir unsur olmasından dolayı üzerinde en çok durulan konunun franchise alan firmaya yönelik "sürekli ve sık bir denetim ve kontrol mekanizmasının" geliştirilmesi gerektiğidir. Bunun sağlanmasında kalite kontrol personelinin firmaya bağlı çalışması gerektiği üzerinde durulmuştur.

Hazır beton sektöründe franchising sisteminin uygulanabilirliği sağlanırken, franchise verilmesi için seçilecek firmanın bölgede tanınan ve işi düzgün yapabileceğine inanılan bir firma olmasının çok önemli olduğu belirtilmiştir. Hazır beton sektöründe kalite kadar önemli diğer bir unsurun firmalara sunulan 
hizmet olduğudur. Bu anlamda kalite kontrol denetim mekanizmasının çok iyi oluşturulması, teftiş kadrosunun kurulması ve habersiz denetimlerin yapılabileceği bir sistemin oluşturulması gerekmektedir.

Görüşülen kişilerin hazır betonda franchising modeli uygulandığında olumlu yanları için verdikleri cevaplar incelediğinde, bu sistem yoluyla katlanılması gerekilen yatırım ve işletme maliyetlerinin bertaraf edileceği belirtilmiştir. $\mathrm{Bu}$ sistemin firma açısından yeni tesis açmadan mevcut pazarı büyütme imkanı tanıması ve Ege Bölgesi dışında yeni pazarlara açılması yönünden bir katkı sağlamasıdır. Bu bağlamda, bu durum yeni bir pazarlama kanalı olacağı ifade edilmiştir. Ayrıca franchise veren firma olarak iş güvenliği ve çevre konularında risklerin karşı tarafa verilecek olduğu da belirtilmiştir.

Franchise alan firma açısından markayı başka bir firmaya vermenin veya isim hakkını kullandırmanın olumlu etkilerinin neler olabileceği incelendiğinde; bilinen bir markayı kullanmak franchise alan firmanın pazar payını, marka değerini ve satışlarını artıracağını, müşteri portföyünü geliştireceğini, daha yüksek fiyatla ürünlerini sunmasını sağlayacağını, yeni firmalara ulaşabileceğini ve hizmet kalitesinin gelişmesini sağlanacağı ifade edilmiştir.

Franchising veren firma olarak hazır beton firmasının bu süreçte karş1laşabilecekleri zorluklar incelendiğinde; Franchise verilen firmalara işin öğretilmesi ile anlaşma bittiğinde bu firmanın bilgi birikimine sahip olacağ 1 endişesi taşıdıklarını belirtmişlerdir. Ayrıca BATIBETON A.Ş. firmasının hali hazırda iyi bilinen marka isminin olması ve firmaların güvenini sağlamış olması, bu şekilde bir franchising alan firmanın takibinin zor olması nedeniyle, algılanan marka değerine zarar verebileceği düşünülmektedir. Kalitenin en önemli risk unsuru olduğu, uygulama üretim ve kalite standartlarının periyodik kontrolünün sağlandığı takdirde başarılı olabileceği ifade edilmiştir. Ayrıca, franchise alan firmanın sözleşmeyi feshetmesi durumda yeni bir firma ile anlaşmanın zor olabileceği ve o bölgedeki piyasanın bu durumdan olumsuz yönde etkilenebileceği de belirtilmiştir. 


\section{İ. KAZANÇOĞLU. - Ö. ÖKTEM}

Franchising sisteminin hazır beton sektöründe sağlıklı bir şekilde işleyebilmesi amacıyla nasıl bir denetim mekanizması oluşturulması gerektiğine ilişkin verilen cevaplar incelendiğinde; franchise alan firmanın başka bir firmadan çimento alıp almadığı ile formülünün sürekli kontrol edilmesi üzerinde durulmuştur. Bu anlamda, sürekli olarak kalite kontrol personelinin firma tarafindan franchise verilen firmada istihdam edilmesi gerektiği düşünülmektedir. Ayrıca hazır beton sektöründe fiyatında önemli bir parametre olduğu için, değişen piyasa fiyatlarına ve maliyetlerine çimento fiyatı belirlenerek, firma tarafından sürekli kontrolünün yapılması gerektiği belirtilmiştir. Yapılacak üretim kontrollerinin ürün kontrol planıyla yapılabileceği, ani ve planlı bir şekilde dönemsel olarak gerçekleştirilmesi gerektiği ifade edilmiştir. İş sağlığı güvenliği, çevre yönetim sistemi ve kalite yönetim sistemi sürekli denetlenmesi gerektiği belirtilmiştir.

Hazır beton sektöründe bölge bazında franchising sistemi uygulamaya konulurken öncelikli bölgeleri belirlemek amacıyla verilen cevaplar incelendiğinde, İzmir merkez ili bazında kendi tesislerinin olması gerekirken, hazır beton tesislerinin olmadığı çevre ilçelerde ve hatta şehir dışındaki bölgelerde franchising sisteminin olması gerektiği üzerinde durulmuştur. Ayrıca piyasa fiyatının düşük olduğu bölgelerde franschising verilirse daha iyi olacağ belirtilmiştir.

Franchising sistemi kurulurken taraflar arasında yapılacak sözleşme süresinin en az beş y1l olması, çimentonun franchise veren firma dışında herhangi bir firmadan alınmamasına yönelik bir maddenin konulması ve makine-ekipman konusunda minimum istenenler sözleşmede listelenmesi gerektiği üzerinde durulmuştur. Sözleşmenin içeriğinde kalite-çevre ve işgücü şartlarının, denetim ve yaptırım mekanizmalarının tümünün sözleşmede ayrıntılı belirtilmesi gerektiği ifade edilmiştir. Sözleşme hükümlerine uyulmaması durumda uyarı verilmesi gerektiği, belirsizliklerin kontrol altına alındığı, belirli sayıda uyarıdan sonra sözleşmenin feshedileceği sözleşmede belirtilmesi 
gerektiği ifade edilmiştir. Ürün ve hizmet kalitesinde oluşacak olumsuz durumlarda firmanın kendini güvence altına almak istediğini ifade etmişlerdir.

Franchising sözleşmesinde royalty bedelinin franchise alan firma için fazla gelebileceği, firmayı zorlayabileceği ve alınmadığg durumda grup şirketinden çimentonun alınması gerektiğini belirtilmiştir. Görüşmelerde bazı kişiler markanın kullandırılması nedeniyle bu bedelin alınması gerektiği ifade etmişlerdir. Bazı katılımcılar ise, dökülen betonun $\mathrm{m}^{3}$ başına pay alınması gerektiğini savunmuşlardır. Franchising anlaşmasının yapıldığı firmanın markası ile birlikte firmanın adının (örnek olarak BATIBETON - MEGA İNŞAAT gibi) kullanımı konusunda franchise verilen firma başka bir isim koymamas1 gerektiği, firmanın marka imajının tek bir isimle anılması gerektiği konusunda görüş belirtmişlerdir. Hazır beton sektöründe BATIBETON markası dışında örnek olarak BETABETON gibi alt marka oluşturarak franchise verilmesi durumuyla ilgili olarak verilen cevaplar incelendiğinde; alt marka oluşturarak böyle bir yapıya geçilmesinin zor olacağı ifade edilmiştir. $\mathrm{Bu}$ anlamda, farklı bir marka oluşturularak, kendi markalarının değeri koruyabileceklerini belirtmişlerdir. Bazı kişilerde ise, tanınmış bir marka varken başka bir markanın tercih edilebileceğinin mümkün olamayacağını ifade etmişlerdir. Franchise vermek adına oluşturulacak yeni markanın fiyatının daha düşük, hizmet kalitesi anlamında daha az beklentiye sahip olunması gerektiğini, ilk başta talep edilmese bile zamanla talep edilebileceğini belirtmişlerdir.

Görüşmelerden elde edilen bulgular araştırma soruları çerçevesinde oluşturulmuş temalara uygun olarak Tablo 2'de özet olarak gösterilmiştir. Bu şekilde, araştırmaya katılan katılımcıların verdikleri cevaplardan alıntılar yapılarak, ayrıntılı bir şekilde gösterilerek, hangi cevabın ne sıklıkla söylendiği belirlenmiştir. Toplam 7 kişiye dayalı olarak yapılan görüşmelerde, bazı katılımcıların ifadelerinde birkaç alt tema birden geçtiği için, onlar bölünerek, iki ve daha fazla ayrı alt temada gösterilmiştir. 


\section{İ. KAZANÇOĞLU. - Ö. ÖKTEM}

Tablo 2. Betimsel Analize Dayalı Olarak Belirlenen Temalar ve Temalara Verilen Cevapların Özet Olarak Değerlendirilmesi

\begin{tabular}{|c|c|c|c|}
\hline TEMALAR & ALT TEMALAR & İFADELER & $\begin{array}{c}\text { KATILIMCI } \\
\text { SAYISI }\end{array}$ \\
\hline \multirow[t]{2}{*}{$\begin{array}{c}\text { FRANCHİSING } \\
\text { SİSTEMİIIN HAZIR } \\
\text { BETON } \\
\text { SEKTÖRÜNDE } \\
\text { UYGULANABILİR } \\
\text { OLUP/OLMADIĞI }\end{array}$} & $\begin{array}{l}\text { "UYGULANABİLİR } \\
\text { OLDUĞU" }\end{array}$ & $\begin{array}{l}\text { "Firmamızda franchising uygulanabilir, ama devamlı olarak firmamızdan } \\
\text { çimentonun alınması için nasıl bir yol izlenebilir o çok önemli ve ayrıca } \\
\text { kalite ve çimento fiyatı konusunda karşı taraf sürekli olarak taleplerde } \\
\text { bulunacaktır. Ve ayrıca isim hakkı verildiği için karşı tarafı (franchise } \\
\text { alan) kontrol edecek mekanizma çok önemlidir." (Erkek, 37) } \\
\text { "Olabilir, herhangi bir franchise bedeli alınmadan bile yapılabilir. Amaç } \\
\text { çimentoyu satmak, bizim tarafimızdan bu iş için konuşlanacak bir ekip } \\
\text { sürekli denetlemelidir."(Erkek,48) } \\
\text { "Bu sistemle yeni pazarlara açılma şansımız olacaktır"(Erkek,38) } \\
\text { "Belirli riskler kabul edilirse kullanılabilir." (Erkek,43) } \\
\text { "Sürekli ve sıkı bir denetimle uygulanabilir bir model” (Erkek,42) olarak } \\
\text { görüşler belirtilmiştir. }\end{array}$ & 5 \\
\hline & $\begin{array}{l}\text { "UYGULANABİLİR } \\
\text { OLMADIĞI" }\end{array}$ & $\begin{array}{l}\text { "Bence uygulama zor. Üretim ve kalite açısından hassas bir ürün olduğu } \\
\text { için franchising uygulaması zor"(Erkek,32) } \\
\text { "Kalitenin kritikliğinden dolayı zor, çok iyi kontrol edilmesi } \\
\text { gerekmektedir. Hatta kalite kontrol personeli bize bağll } \\
\text { olabilir"(Erkek,44) }\end{array}$ & 2 \\
\hline \multirow{2}{*}{$\begin{array}{c}\text { HAZIR BETON } \\
\text { SEKTÖRÜNDE } \\
\text { FRANCHİSING } \\
\text { MODELİ } \\
\text { UYGULANDIĞINDA } \\
\text { FİRMAYA KATTIĞI } \\
\text { OLUMLU YANLAR }\end{array}$} & $\begin{array}{c}\text { "PAZARI BÜYÜTMEK” } \\
\text { AVANTAJI }\end{array}$ & $\begin{array}{l}\text { "Pazarı büyütmek en olumlu yanı olacaktır” (Erkek,32) } \\
\text { "Başka şehirlerde de hatta Ege Bölgesi dışında da pazarlar yakalamak bu } \\
\text { model ile mümkün olacaktır." (Erkek,42) } \\
\text { "Yeni tesis açmadan iyi bir büyüme stratejisi olacaktır" (Erkek,38) }\end{array}$ & 3 \\
\hline & $\begin{array}{l}\text { "YENİ BİR } \\
\text { PAZARLAMA } \\
\text { KANALI" }\end{array}$ & "Firmamız için yeni bir pazarlama kanalı olacaktır” (Erkek,48) & 1 \\
\hline
\end{tabular}


Dokuz Eylül Üniversitesi İktisadi ve İdari Bilimler Fakültesi Dergisi Cilt:31, Sayl:2, Yll:2016, ss. 251-285

\begin{tabular}{|c|c|c|c|}
\hline & $\begin{array}{l}\text { "MALIYYETİ } \\
\text { DÜŞÜRME" }\end{array}$ & $\begin{array}{l}\text { "Çimentoyu en büyük tüketme kaynağ hazır beton olduğu için yatırım } \\
\text { maliyetleri ve işletme maliyetleri bertaraf edilecektir." (Erkek, 37) } \\
\text { "Yeni tesis kurmak için para ve zaman sarf etmekten çok daha kolay } \\
\text { olacaktır." (Erkek,43) }\end{array}$ & 2 \\
\hline & $\begin{array}{l}\text { "RİSKLERDEN } \\
\text { KAÇINMA" }\end{array}$ & $\begin{array}{l}\text { "En önemlisi getirisi iş güvenliği ve çevre açısından riskleri karşı tarafin } \\
\text { alacak olmasıdır" (Erkek,44) }\end{array}$ & 1 \\
\hline \multirow[t]{4}{*}{$\begin{array}{c}\text { FRANCHİSİNG } \\
\text { VEREN FİRMA } \\
\text { OLARAK HAZIR } \\
\text { BETON FİRMASININ } \\
\text { BU SÜREÇTE } \\
\text { KARŞILAŞABİLECEĞİ } \\
\text { ZORLUKLAR }\end{array}$} & $\begin{array}{l}\text { "MARKAYI VE } \\
\text { MARKA DEĞERINİ } \\
\text { OLUMSUZ } \\
\text { ETKİLEMESİ" }\end{array}$ & $\begin{array}{l}\text { "Franchise alan firmalar tekil firmalar olabileceği için marka değerimizi } \\
\text { düşürebilirler"(Erkek,48) } \\
\text { "Markamızı olumsuz etkileyecek durumlar yaşanabilir", (Erkek,38) } \\
\text { "Kalite anlamında büyük risk var, marka değerini aşağl çekmemek için bu } \\
\text { konuda önlemler alınmalıdır." (Erkek,43) } \\
\text { "Franchise alan firmanın takibi zor olabilir ve marka değerine zarar } \\
\text { verebilir ve yapabileceği her kötü uygulama ismimize zarar } \\
\text { verebilecektir" (Erkek,32) } \\
\text { "Franchise alan firma, uygulama standartları kontrol edilmez ise marka } \\
\text { değerimizi düşürür." (Erkek,42) }\end{array}$ & 5 \\
\hline & $\begin{array}{l}\text { "PAZAR PAYINI } \\
\text { ETKİLEMESİ" }\end{array}$ & $\begin{array}{l}\text { "Franchise alan firma sözleşmeyi terk ederse yeni bir firma ile anlaşmak } \\
\text { zor olabilir bu da bizim o bölgedeki piyasamızı etkiler" (Erkek,44) }\end{array}$ & 1 \\
\hline & $\begin{array}{l}\text { "BİLGİ BİRIKİMİ VE İŞ } \\
\text { YAPIŞ ŞEKLININ } \\
\text { ÖĞRENILMESI" }\end{array}$ & $\begin{array}{l}\text { "Franchise alan firmalara iş ögretilecek ve bu firmalarla anlaşma } \\
\text { bittiğinde senin bilgi birikimine sahip olacaklar" (Erkek, 37) }\end{array}$ & 1 \\
\hline & $\begin{array}{l}\text { "BETON } \\
\text { FIYATLARININ VE } \\
\text { MALIYETIN } \\
\text { KONTROLÜ" }\end{array}$ & $\begin{array}{l}\text { "Piyasanın beton fiyatının sürekli olarak tarafimızca kontrolü } \\
\text { gerekmektedir.” (Erkek,42) } \\
\text { "... Çimento fiyatı belirlenmesinde, maliyet skalası olmalı ve değişen } \\
\text { piyasa fiyatlarına ve maliyetlere göre çimento fiyatı belirlenebilir. Bunun } \\
\text { için sürekli denetim gereklidir" (Erkek,43) }\end{array}$ & 2 \\
\hline
\end{tabular}




\section{İ. KAZANÇOĞLU. - Ö. ÖKTEM}

\begin{tabular}{|c|c|c|c|}
\hline \multirow[t]{2}{*}{$\begin{array}{l}\text { FRANCHİSING } \\
\text { SISTEMININ HAZIR } \\
\text { BETON } \\
\text { SEKTÖRÜNDE } \\
\text { SAĞLIKLI BİR } \\
\text { ŞEKİLDE } \\
\text { İŞLYEBİLMESİ } \\
\text { AMACIYLA } \\
\text { OLUŞTURULMASI } \\
\text { GEREKEN DENETIM } \\
\text { SISTEMİ }\end{array}$} & $\begin{array}{l}\text { "ÜRETIM VE KALITE } \\
\text { STANDARTLARININ } \\
\text { KONTROLÜ" }\end{array}$ & $\begin{array}{l}\text { "Ciddi bir kontrol birimi oluşturulmalıdır. Üretim ve kalite standartlarının } \\
\text { periyodik olarak kontrol edilmesi gerekmektedir." (Erkek,32) } \\
\text { "Denetim mekanizması iş sağlığl güvenliği, Çevre yönetim sistemi, kalite } \\
\text { yönetim sistemi açısından sürekli olarak denetlenmelidir. Özellikle } \\
\text { şantiyelerde denetim şart" (Erkek,44) } \\
\text { "Dönemsel kontrol önemli, sürekli kontrol işsin riskini de paylaşmak } \\
\text { anlamını taşlyabilir. Ani kontroller ve planlı kontroller ile denetlemeler } \\
\text { yapılabilir" (Erkek,38) } \\
\text { "Bizden başka firmalardan çimento alıp almadı̆ğl, formül kontrolü gibi } \\
\text { konular sürekli kontrol edilmelidir. Marka değerini korumak amaçlı } \\
\text { dizaynların uygulanması ve kontrolü yaplmalıdır....." (Erkek, 37) }\end{array}$ & 4 \\
\hline & $\begin{array}{c}\text { “KALİTE KONTROL } \\
\text { PERSONELINININ } \\
\text { SAĞLANMASI" }\end{array}$ & $\begin{array}{l}\text { “.... Çok iyi bir denetim mekanizması kurmak, teftiş kadrosu kurmak ve } \\
\text { habersiz denetimler önemlidir. Özellikle kalite kontrol sonuçlarını, eş } \\
\text { zamanlı takip edeceğimiz bir sistem kurulabilir.” (Erkek,48) } \\
\text { “..... Sürekli bir personel istihdam edilerek kontrol mekanizması } \\
\text { sağlanabilir” (Erkek,42) } \\
\text { ".... Hatta sürekli olarak bir kalite kontrol personeli şirketimizce o tesiste } \\
\text { istihdam edilebilir”"(Erkek, 37) }\end{array}$ & 3 \\
\hline $\begin{array}{l}\text { FRANCHİSING } \\
\text { SISTEMİ } \\
\text { KURULURKEN } \\
\text { TARAFLAR } \\
\text { ARASINDA }\end{array}$ & $\begin{array}{l}\text { "ÇİMENTONUN } \\
\text { FRANCHISE ALAN } \\
\text { FİRMADAN SATIN } \\
\text { ALINMASI" }\end{array}$ & $\begin{array}{l}\text { "Çimentoyu franchise alan firma bizden almalıdır, zaten amacımız } \\
\text { çimento satmak." (Erkek, 37) } \\
\text { "Detaylı bir sözleşme şart. Sözleşmeye konulmasında yasal bir sakınca } \\
\text { yoksa çimentonun bizden başka bir firmadan alınmaması gerektiğine dair } \\
\text { bir madde konulmalıdır” (Erkek,43) } \\
\text { "Çimento bağlantılı bir sözleşme olabilir, kalite-çevre ve iş güvenliği } \\
\text { şartları sözleşmeye konulsun." (Erkek,44) } \\
\text { "Ciddi bir sözleşme kesinlikle gereklidir. En az beş yıllık bir sözleşme } \\
\text { yapılmalıdır. Çimentoyu bizden almalı ve makine-ekipman konusunda } \\
\text { minimum istenenler sözleşmede listelenmelidir." (Erkek,32) }\end{array}$ & 4 \\
\hline
\end{tabular}


Dokuz Eylül Üniversitesi İktisadi ve İdari Bilimler Fakültesi Dergisi Cilt:31, Sayl:2, Yll:2016, ss. 251-285

\begin{tabular}{|c|c|c|c|}
\hline \multirow[t]{2}{*}{$\begin{array}{l}\text { YAPILACAK } \\
\text { SÖZLEŞMENIN } \\
\text { İÇERİĞ }\end{array}$} & $\begin{array}{l}\text { "SÖZLEŞMEDE } \\
\text { YAPTIRIM } \\
\text { MEKANIZMASININ } \\
\text { İŞLEMESI'” }\end{array}$ & $\begin{array}{l}\text { "Sözleşme hükümlerine uyulmadı̆̆ında uyarı verileceği ve belirli bir } \\
\text { sayıda uyarıdan sonra sözleşmenin feshedileceği sözleşmede } \\
\text { belirtilmelidir." (Erkek,42) } \\
\text { "Sözleşme çok önemli. Tüm denetim mekanizmaları sözleşmede tarif } \\
\text { edilmelidir. Özellikle ..... yaptırımların da ne olacağ sözleşmede } \\
\text { belirtilmelidir." (Erkek,38) }\end{array}$ & 2 \\
\hline & $\begin{array}{l}\text { "ÜRÜN VE HİZMET } \\
\text { KALITESİNE DİKKAT } \\
\text { EDİLMESİ” }\end{array}$ & $\begin{array}{l}\text { "Sözleşmede, ürün kalitesi ve hizmet kalitesinde oluşacak olumsuzluklarda } \\
\text { kendimizi güvence altına almalıyız. Bu kapsamda belirsizliklerin kontrolü } \\
\text { çok önemli, bu sebeple ayrıntılı bir sözleşme hazırlanmalıdır.” (Erkek,48) } \\
\text { “.......kalite açısından yapılması gerekenler sözleşmede açık bir şekilde } \\
\text { ortaya konmall ve .....”(Erkek,38) }\end{array}$ & 2 \\
\hline \multirow{4}{*}{$\begin{array}{c}\text { HAZIR BETON } \\
\text { SEKTÖRÜNDE } \\
\text { FRANCHISIING } \\
\text { SISTEMİ } \\
\text { UYGULAMAYA } \\
\text { KONULURKEN } \\
\text { ÖNCELIKLİ } \\
\text { BÖLGELERIN } \\
\text { BELIRLENMESİ }\end{array}$} & $\begin{array}{l}\text { "İZMIR'İN ÇEVRE } \\
\text { İLÇELERINNDE } \\
\text { FRANCHİSING } \\
\text { SİSTEMİ” }\end{array}$ & $\begin{array}{l}\text { "İzmir merkezde biz olmalıyı, çevre ilçelerde franchising sistemi olabilir" } \\
\text { (Erkek, 37) } \\
\text { "Il merkezleri haricinde franchising verilebilir" (Erkek,48) } \\
\text { "Il merkezlerinde kendi tesislerimiz olmalıdı ve küçük ilçelerde } \\
\text { franchising verilebilir. Merkeze uzak illerde de franchise verilebilir." } \\
\text { (Erkek,32) }\end{array}$ & 3 \\
\hline & $\begin{array}{l}\text { "PIYYASA FIYYATININ } \\
\text { DÜŞÜK OLDUĞU } \\
\text { YERLER" } \\
\end{array}$ & $\begin{array}{l}\text { "Piyasa fiyatının düşük olduğu yerlerde kesinlikle franchising } \\
\text { verilmelidir." (Erkek,44) }\end{array}$ & 1 \\
\hline & $\begin{array}{l}\text { "FİRMANIN SATIŞ } \\
\text { YAPMADIĞI } \\
\text { BÖLGELER } \\
\text { SEÇİLEBİLIR" }\end{array}$ & $\begin{array}{l}\text { "Bizim olmadı̆̆ımız bölgeler seçilmelidir" (Erkek,38) } \\
\text { "Şu anda olmadığımız ve şehir merkezi dışındaki bölgeler için franchise } \\
\text { sistemi tercih edilebilir" (Erkek,43) } \\
\text { "Şu anda mevcut durumda olmayan tesislerimiz yerine franchise tesisler } \\
\text { kurulabilir." (Erkek,42) }\end{array}$ & 3 \\
\hline & $\begin{array}{l}\text { "ROYALTY } \\
\text { BEDELININ } \\
\text { ALINMASI" }\end{array}$ & $\begin{array}{l}\text { "Kesinlikle alınmalı neticede markanızı kullandırıyorsunuz." (Erkek,38) } \\
\text { "Kesinlikle hem franchise bedeli hem de royalty bedeli alınmalıdır." } \\
\text { (Erkek,32) }\end{array}$ & 3 \\
\hline
\end{tabular}




\section{İ. KAZANÇOĞLU. - Ö. ÖKTEM}

\begin{tabular}{|c|c|c|c|}
\hline \multirow{3}{*}{$\begin{array}{c}\text { FRANCHİSING } \\
\text { SÖZLEŞMESINDE } \\
\text { BELIRLENEN } \\
\text { ORANLARDA YÜZDE } \\
\text { OLARAK ÖDENEN } \\
\text { ROYALTY BEDELİ }\end{array}$} & & "Dökülen $m^{3}$ beton başına bir pay alınmalıdır" (Erkek,44) & \\
\hline & $\begin{array}{c}\text { "ROYALTY } \\
\text { BEDELININ } \\
\text { ALINMAMASI" }\end{array}$ & $\begin{array}{l}\text { "Alınmasına gerek olmadı̆̆ını düşünüyorum, pazarın durumuna göre bu } \\
\text { konu değerlendirilebilir.” (Erkek,42) } \\
\text { "Royalty bedeli alınmasa da olur, çimentonuzu kullanmaları yeterlidir." } \\
\text { (Erkek,43) } \\
\text { "Royalty bedeli franchise alan firma için fazla gelebilir. İlk aşamada } \\
\text { firmayı zorlayabilir" (Erkek, 37) }\end{array}$ & 3 \\
\hline & $\begin{array}{c}\text { "SÖZLEŞMENIN } \\
\text { YAPISINA BAĞLI } \\
\text { DEĞİŞEBİLIR" }\end{array}$ & "Sözleşmenin yapısına bağlı olarak değişebilir" (Erkek,48) & 1 \\
\hline \multirow[b]{2}{*}{$\begin{array}{c}\text { FRANCHİSING } \\
\text { ANLAŞMASININ } \\
\text { YAPILDIĞI } \\
\text { FİRMANIN MARKASI } \\
\text { İLE BİRLIKTE } \\
\text { FİRMANIN ADININ } \\
\text { (ÖRNEK OLARAK } \\
\text { BATIBETON - MEGA } \\
\text { İNŞAAT GİBİ) } \\
\text { KULLANIMI }\end{array}$} & $\begin{array}{l}\text { "BAŞKA BİR MARKA } \\
\text { ISIMIMININ } \\
\text { KULLANILMASI" }\end{array}$ & $\begin{array}{l}\text { "Franchise tesislerini diğer firmalardan ayırmak için anlamlı olabilir." } \\
\text { (Erkek,42) }\end{array}$ & 1 \\
\hline & $\begin{array}{l}\text { "BAŞKA BİR MARKA } \\
\text { İSMININ } \\
\text { KULLANILMAMASI" }\end{array}$ & 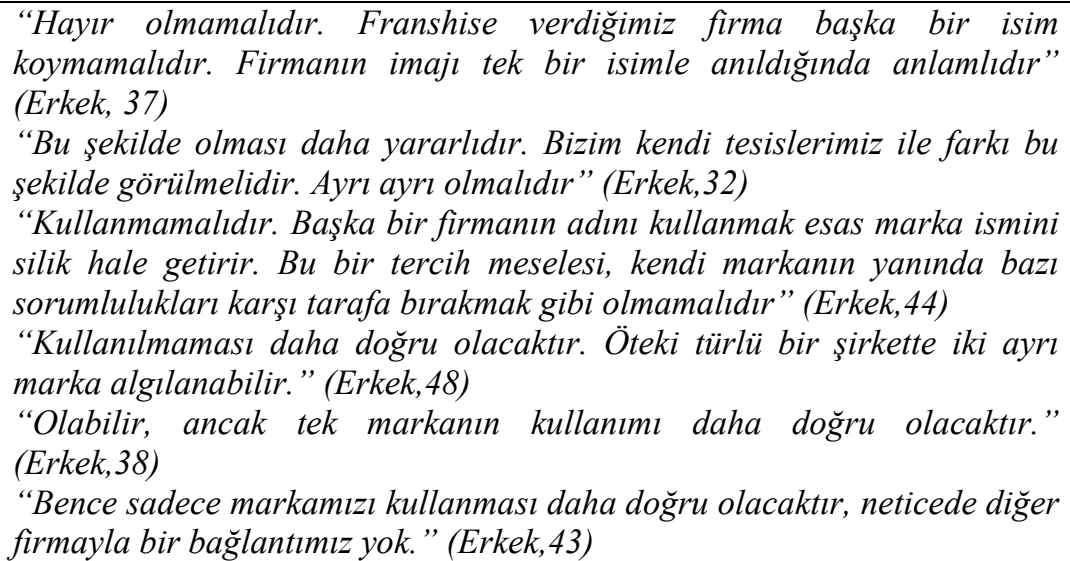 & 6 \\
\hline
\end{tabular}


Dokuz Eylül Üniversitesi İktisadi ve İdari Bilimler Fakültesi Dergisi Cilt:31, Sayl:2, Yll:2016, ss. 251-285

\begin{tabular}{|c|c|c|c|}
\hline $\begin{array}{l}\text { HAZIR BETON } \\
\text { SEKTÖRÜNDE } \\
\text { BATIBETON } \\
\text { MARKASI DIŞINDA } \\
\text { ÖRNEK OLARAK } \\
\text { BETABETON GIBİ } \\
\text { ALT MARKA }\end{array}$ & $\begin{array}{c}\text { “ALT MARKA } \\
\text { OLUŞTURULMASI” }\end{array}$ & $\begin{array}{l}\text { "Farklı bir marka da oluşturulabilir. Diğer markanın değeri korunmuş } \\
\text { olur." (Erkek,44) } \\
\text { "Ilk başta bir rağbet görmese bile zamanla rağbet görecektir"” (Erkek,48) } \\
\text { "Evet olabilir. Diğer marka bir süre sonra ikincil bir marka olabilecektir. } \\
\text { Fiyat olarak düşük ve hizmet kalitesi olarak da daha az beklentili bir } \\
\text { marka oluşturulabilir. Piyasa da bunu bir süre sonra kabul edebilir." } \\
\text { (Erkek,38) } \\
\text { "Kendi markamızı korumak adına bu da bir çözüm olabilir".," (Erkek,43) }\end{array}$ & 4 \\
\hline $\begin{array}{c}\text { OLUŞTURARAK } \\
\text { FRANCHISE } \\
\text { VERILIMESİ }\end{array}$ & $\begin{array}{c}\text { "ALT MARKA } \\
\text { OLUŞTURULMAMASI” }\end{array}$ & $\begin{array}{l}\text { "Alt marka oluşturmak endüstriyel bir ürün için, markamız ile bile bu } \\
\text { sistemi cazip kllmak zor iken alt marka ile bu sistemi kurmak zor } \\
\text { olacaktır." (Erkek, 37) } \\
\text { "Rağbet göreceğini sanmıyorum” (Erkek,32) } \\
\text { "Tanınmış bir marka dururken başka bir markayı tercih edeceklerini } \\
\text { sanmıyorum. Neticede kendi isimlerini taşıyan bir firma kendilerine daha } \\
\text { cazip gelebilir." (Erkek,42) }\end{array}$ & 3 \\
\hline
\end{tabular}




\section{İ. KAZANÇOĞLU. - Ö. ÖKTEM}

Derinlemesine görüşme sonucunda ortaya çıkan tespitler Şekil 2'de gösterilmiştir.

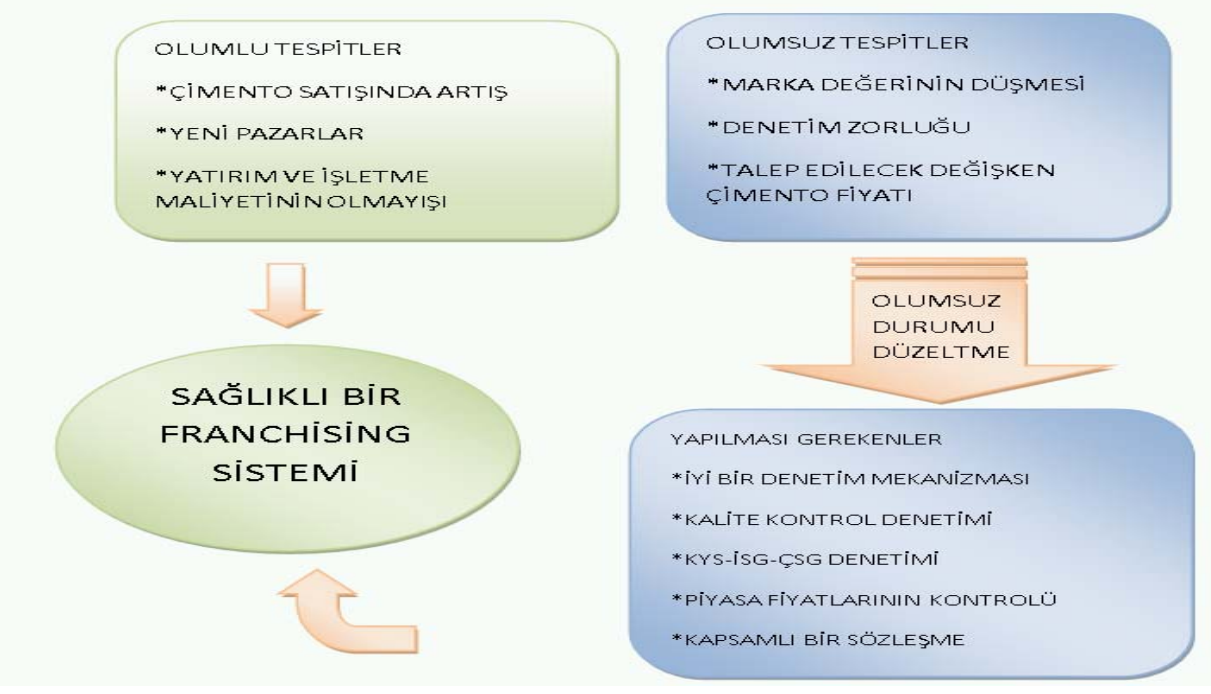

Şekil 2. Derinlemesine Görüşme Sonucunda Ortaya Çıkan Tespitler

Yapılan görüşmelere dayandırılarak yapılan değerlendirmelerde özet olarak çıkan sonuçlar sıralandığında:

- Franchising sistemi hazır beton sektörü için uygulanabilir bir sistem olduğu düşünülmektedir.

- Torba-dökme çimento satışı, hazır beton üretimi gibi çimentonun satışına yönelik pazarlama kanallarına bir alternatif olarak franchising modeli uygulanabileceği belirlenmiştir.

- Oluşturulacak bu franchising modelinin olumlu özellikleri, yeni pazarlara açılabilmeyi, yeni çimento satış kanallarının oluşturabilmeyi ve tüm bunlar yapılırken sıfır işletme ve yatırım maliyeti gerektirdiği tespit edilmiştir.

- $\mathrm{Bu}$ franchising modelinin olumsuz özellikleri ise, marka değeri ile ilgili bir risk oluşturması, franchise alan firmanın denetlenmesi konusunda zorluk yaşanabileceği endişesi, firmaya tarafımızdan tedarik edilecek çimento fiyatının tespiti konusundaki hassasiyetler olarak sıralanmaktadır. 
- İyi bir denetim mekanizması oluşturulması gerektiği ve yapılan görüşmelerde özellikle kalite kontrol ve üretim süreçlerinin denetlenmesi konusunun çok hassas olunduğu belirtilmiştir. İlgili firmanın ayrıca çevre ve iş sağlığı konularında denetlenmesi gerekmektedir. Bu şekilde, piyasadaki hazır beton satış fiyatları, hammadde fiyatlarının takip edilmesi ile çimento fiyatının pazara uyum sağlayacak şekilde ayarlanması sağlanmış olacaktır.

- Kapsamlı ve detaylı bir sözleşme ile denetim mekanizması ve denetimde rastlanacak uygunsuzlukların sonuçlarına dair net maddelerin bulunması gerekmektedir.

- Franchise kapsamında ya sadece BATIBETON markasının kullanılması ya da tercihen ikincil bir markanın kullanılması gerektiği ifade edilmiştir. İkincil bir marka kullanıldığ 1 durumda markanın çok fazla talep görmeyeceği konusunda yöneticilerin hassasiyetlerinin olduğu tespit edilmiştir.

- Doğru bölge ve doğru firma seçimi ve hazır beton üretimdeki tüm süreçlerin (üretim-kalite kontrol-işletme-satınalma-insan kaynakları-satışpazarlama) denetlenebileceği bir denetim sisteminin kurulması ve bu denetim sistemi ile ilgili tüm hassasiyetlerin sözleşmeye yansıtılmasının marka değerini korumak açısından tüm görüşülen yöneticilerin ortak noktada birleştikleri görülmüştür.

\section{SONUÇ VE ÖNERILER}

Türkiye'deki hazır beton sektörünün yaşadığı en önemli sorun, Nart (2005)'ın çalışmasında da ifade ettiği gibi, standart dışı-kalitesiz üretim ve faturasız satışlarla haksız rekabete yol açan kayıt dışı hazır beton üreticilerinin varlığıdır. İnşaat şantiyelerinde standartlara uyulmadan kurulan beton santralleri denetim dışı üretim yapıp, görüntü ve çevre kirliliğine yol açmaktadır. Aynı zamanda bu durum maddi kaynak israfi da yaratmaktadır. Bu sorunun çözümünde franchising sistemi bir model olarak kullanıldığında kayıt dışı 


\section{İ. KAZANÇOĞLU. - Ö. ÖKTEM}

haksız kazanç sağlayan firmaların franchising sistemi yoluyla kayıt altına alınarak, franchisor firması tarafından bir denetim mekanizmasının işletilmesinin sektöre önemli bir katk1 sağlayacağı düşünülmektedir. $\mathrm{Bu}$ kapsamda araştırmada, Türk pazarında hazır beton sektörü için yeni bir kavram olan franchising sistemi incelenerek, firmanın bakış açısı, olumlu ve olumsuz yönleriyle birlikte ortaya konulmuştur. $\mathrm{Bu}$ anlamda gerek literatürde endüstriyel firmalarda franchising uygulamalarına yönelik bir çalışmanın olmayışı, gerekse franchising iş modelini kullanmak isteyen firmalara sunulacak önerilerle çalışmanın sektöre de katkı sağlayacağı düşünülmektedir. Çalışmada hazır beton sektöründe franchising sisteminin, özellikle gelişmemiş piyasalarda şehir dışında, büyük ilçelerdeki bölgelerde uygulanabilir bir iş modeli olabileceği belirlenmiştir. Planlanabilecek modelde mevcut hazır beton tesisleri aynen korunarak, Johnson (2010) ile Sirichalermpong ve Chansangavej (2012b) çalışmasında belirttiği gibi büyüme stratejisinde pazar payının genişletilmesine yardımcı olacak ve kendi yatırımı ile birlikte franchise tesisi kurabileceklerdir. Kurulması düşünülen franchising sisteminde dikkate alınması gereken unsurlar incelendiğinde;

Yer ve bölge seçimi: Yer seçimi olarak özellikle gelişmekte olan bölgelerde kendi hazır beton tesislerini kurmak yararlıken, daha az gelişmiş bölgelerde franchise sisteminin kurulması daha doğru olacağı tespit edilmiştir. Ege bölgesinde ve yakın diğer il ve ilçelerde, hazır beton tesisi olmayan yerlerde potansiyel franchise tesisi için uygun pazarlar olarak görülmektedir. Bu bulgu Sirichalermpong vd. (2012) çalışması sonuçlarında, özellikle pazar çekiciliğinin yüksek, pazarın gelişmişliğinin düşük olduğu yeşil alan ile pazar çekiciliğinin düşük, pazarın gelişmişliğinin yüksek olduğu bölgeler olan fidanlıklarda franchising modelinin bir alternatif olarak kullanılabileceğini belirterek bu çalışmayı desteklemektedir. Ayrıca, pazarın gelişmişliği ile çekiciliğinin yüksek olduğu şehir merkezi gibi yerler olan petrol sahalarında hazır beton tesislerinin kendi tesisleriyle yer alması gerektiği çalışma sonuçlarıyla uyuşmaktadır. 
Franchise alan firma seçimi: Firma seçimi yapılmadan önce başvuruda bulunan firma maddi ve iş yapışı açısından çok detaylı bir şekilde incelenmesi, stratejik ve operasyonel destek satın alabileceği firmanın seçilmesi, Velentzasa ve Broni (2013) çalışma sonuçlarını da desteklemektedir. Ayrıca, kurumsal bir firmayla birlikte çalışılması ve uygunluk açısından denetlenmelidir. Ön denetimi geçen firmalarla franchising anlaşması yapılmalıdır.

Sistem kurulması ve kontrol noktaları: İş akışındaki tüm süreçler detaylı bir şekilde denetlenmeli ve sistem tüm noktalarda denetlenebilecek şekilde sözleşme hazırlanmalıdır. Franchise alan firmaya verilecek teknik destek ve ilgili firmadan istenecek teknik ekipman yeterliliği sözleşmede belirtilmelidir. Bu bulgu Salar ve Salar (2014) ile Ulaş (2015)'ın çalışmalarında belirttiği gibi franchising sisteminin iyi bir şekilde düzgün işleyebilmesi için iyi bir sözleşmeye dayalı olması bulgusunu desteklemektedir. Satış biriminin müşteriyle ilişkileri, piyasada oluşan rekabet şartlarına uygun fiyatlandırma (Pazarlama-Satış Süreci); alınan işe göre yeterli ekipmanın olup olmadığı; işe uygun iş programın hazırlanması (Planlama Süreci), hammadde ve ürün denetimi (Üretim Süreci), talep edilen ürünün standartlara uygun formülünün yapılması (Tasarım Süreci); ilgili hammaddelerin ve ekipmanların standartta ve piyasa şartlarına uygun olarak seçimi ve tedariği (Satınalma Süreci); tüm çalışanların firmanın marka değerini koruyacak şekilde seçilmesi ve eğitilmesi (İnsan Kaynakları Süreci); bakım ve onarım faaliyetlerinin üretimin devamlılığını sağlayacak şekilde yapılması (Destek Süreci) gibi faaliyetler düzenli olarak denetlenmelidir. Piyasadaki ürün fiyatları düzenli olarak takip edilmeli ve franchise alan firmanın ayakta kalabilmesini sağlayacak çimento fiyatı belirli dönemlerde revize edilmelidir. Ayrıca siparişin standartlara uygun ve kaliteli bir üretime dönüşmesi için siparişin verilmesinden ürünün müşteriye sevk edilmesine kadar geçen her aşamanın kontrol edilmesi gerekmektedir. Hazır betonda siparişin doğru alınması, sipariş ile ilgili doğru formülasyonun oluşturulup, seçilmesi ve hammaddenin sürekli kontrolü, üretimde kullanılan tüm tartım aletlerinin denetimi, üretim süreci sonunda oluşan ürünün 


\section{İ. KAZANÇOĞLU. - Ö. ÖKTEM}

denetlenmesi ve teslim edilip şantiyede kalıba yerleştirilinceye kadar aynı standardın korunması sağlanmalıdır. Franchise veren firma tarafindan bu kontrol sürecinin önemi Rubin (1978)'in çalışmasında da belirtilmiştir.

Sözlesme: Tüm kontrol noktaları sözleşmede belirtilmeli, düzenli denetimin sonucunda oluşabilecek uyarı veya sözleşme feshi durumları açıç̧a ortaya konulmalıdır.

Düzenli denetim: Düzenli denetim için bir kontrol birimi kurulmalı ve tüm kontrol noktaları düzenli olarak kontrol edilmelidir. Bu kontrol üretim noktaları dışında tüm fonksiyonel süreçleri-satınalma-pazarlama-insan kaynakları vs. kapsamalıdır. $\mathrm{Bu}$ kontroller düzenli ya da ani bir denetim olarak gerçekleştirilecek şekilde sistem kurulmalıdır.

Sonuç olarak hazır betonda franchising marka değerinin korunmasının sağlanması durumunda firma için çok daha hızlı ve zahmetsiz bir alternatif büyüme modeli olacaktır. Sistem kurulurken yukarıdaki aşamalar üzerinden sistem kurulmalı ve bu sistemin daha sağlıklı işleyebilmesi açısından ilk önce pilot uygulama olarak bir tesisle franchise sistemine geçilmeli ve buradan elde edilecek tecrübelerle sistemin genele yayılması sağlanmalıdır. Araştırmanın sadece hazır beton sektöründe faaliyet gösteren tek bir firmada yapılmış olması, Ege Bölgesi'ndeki diğer firmaların çalışmaya dahil edilmemiş olması çalışmanın kısıtını oluşturmaktadır. Nitel bir araştırma olduğundan çalışma sonuçları sektör için genellenebilir değildir. Bu bakımdan, çalışmanın sonuçları dikkate alınarak oluşturulacak bir anket çalışmasıyla sektördeki diğer hazır beton firmalarının dahil olabileceği bir nicel çalışma yapılabilir. Bu şekilde, franchising sisteminin sektörde benimsenmesi için hangi unsurların etkili olduğu daha detaylı değerlendirilebilir.

\section{KAYNAKÇA}

ARICAN, E., ZENGIN, S. (2015), "Bankac1l1kta Franchising: Dünya Örnekleri ve Türkiye İçin Model Önerisi", İstanbul Ticaret Üniversitesi Sosyal Bilimleri Dergisi, 14(28), 1-36. 
ASLANOĞLU, S. (2007), "Bir Büyüme Stratejisi Olarak Franchising Sistem Firmalar Açısından Önemi, Mevzuat Boyutu Ve Muhasebe Uygulaması", Afyon Kocatepe Universitesi, I.I.I.B.F. Dergisi, C.IX, S.1.

CANDAN, B. (2000), "Üniversiteli Öğrencilerin Franchising Sistemine Göre İşleyen Fast Food Restoranları Tercih Edip Etmeme Sebepleri Üzerine Bir Saha Araştırması", Pazarlama Dünyası Dergisi, Y. 14.

CEBECI, R.(2005), Franchising Rehberi, KOSGEB Girişimciliği Geliştirme Merkezi, Ankara.

COMBS, J. G., KETCHEN, Jr. D. J., HOOVER, V. L. (2004),“A Strategic Groups Approach to the Franchising - Performance Relationship", Journal of Business Venturing, 19, (6),877-897.

GÖRKEM, O. (2015), "Franchising Sistemi Uygulanan Fast Food İşletmelerinde Örgütsel Bağl11ık: Denizli Örneğì", Işsletme Araştırmaları Dergisi, 7/1,267-279.

Hazır Beton Birliği, Hazır Beton Sektörü İstatistikleri, 2014. http://www.thbb.org/sektor/istatistikler/, (21.12.2015).

JOHNSON, MW. (2010), Seizing The White Space: Growth And Renewal Through Business Model Innovation, Harvard Business Press, USA. Boston. ISBN 978-1-4221-2481-9.

KEEGAN, W., GREEN, M. C. (2008), Global Marketing, Fifth Edition, Pearson International Edition.

KÜÇÜK, B. (2011), "Uluslararası Giriș Stratejilerinde Franchising Sistemi ve Bir Uygulama”, Karadeniz Teknik Üniversitesi Sosyal Bilimler Dergisi, 2, 1729.

NART, S. (2005), “Türkiye'de Franchising Sisteminin Gelişimi ve Franchise Alan Girişimcilerin İş Memnuniyeti Belirleyicilerinin Analizi Üzerine Bir Araştırma”, Kocaeli Üniversitesi Sosyal Bilimler Enstitüsü Dergisi, (10) / 2, 123-149.

RUBIN, P.H. (1978), "The Theory of The Firm And Structure of The Franchise Contract", Journal of Law and Economics, 21, 223-33. http://dx.doi.org/10.1086/466918.

SALAR, M., SALAR O. (2014), "Determining Pros And Cons Of Franchising By Using SWOT Analysis", 2nd World Conference on Design, Arts and Education DAE-2013, Procedia - Social and Behavioral Sciences, 122, 515 519. 


\section{İ. KAZANÇOĞLU. - Ö. ÖKTEM}

SALEH, S, KLEINER, BH. (2005), "Effective Franchise Management", Management Research News, 28(2/3), 74-79.

SHERMAN, A. J. (2011), Franchising \& Licensing: Two Powerful Ways to Grow Your Business in Any Economy, American Management Association.

SIRICHALERMPONG, J., CHANSA-NGAVEJ, C. (2012a), "Factors Influencing the Decision to Join Non-Retail Franchise Business with an Application to Ready-mixed Concrete Industry in Thailand", Journal of Management Research Makrokthink Institute, 4(3), 232-246.

SIRICHALERMPONG, J., CHANSA-NGAVEJ, C. (2012b), "Perceived Benefit and Franchisor Assistance Supporting the Competitiveness of Nonretail Franchise Business with Application to Ready-mixed Concrete Industry in Thailand", Business Management Dynamics, 1(12), 48-58.

SIRICHALERMPONG, J., CHANSA-NGAVEJ, C., NAI, S. (2012), "NonRetail Franchising Business Model: Factors For Strategic Decisions in The Formation Phase", Asian Journal of Management Research, 3(1), 282-290.

TOSUN, F., EMIRZA, E. (2014), "Endüstriyel Pazarlarda Müssteri Sadakati, Müşteri Memnuniyeti Ve Müşteri Değerinin Ölçülmesi "Boyçelik" İşletmesine Yönelik Bir Alan Araştırması”, Süleyman Demirel Üniversitesi İktisadi ve İdari Bilimler Fakültesi Dergisi, 19(4), 271-286.

TÜRKSOY, S.S., KAYGALAK, S., KOÇAK, N., (2013), "Uluslararası Otel İşletmelerinin Büyüme Stratejileri: Hilton Worldwide Türkiye Örneği”, İşletme Fakültesi Dergisi, 14(2), 89-108.

ULAŞ, D. (2015), Franchising Sistemi Kitabı, Nobel Yayın, Ankara.

Ülke Bazında Hazır Beton İstatistikleri (2014), http://www.betonvecimento.com/ulke-bazinda-hazir-beton-istatistikleri-2014, (12.12.2015).

ÜNÜSAN, Ç. (1998), "Ülkemizde Franchising Sistemleri ile Bağımsız Perakendecilerden Alışveriş Yapan Tüketicilerin Tatmin Düzeylerinin Karşılaştırılması Araştırılması”, Pazarlama Dünyası Dergisi, 12, 72.

VELENTZASA, J., BRONI G. (2013), "The Business Franchise Contract As A Distribution Marketing System: Free Competition And Consumer's Protection", International Conference On Applied Economics (ICOAE), Procedia Economics and Finance 5, $763-770$. 
WANG, E., TAI, J., WEI, H. (2006), "A Virtual Integration Theory Of Improved Supply-Chain Performance”, Journal of Management Information System, 23(2), 41-64.

YAN, R., WANG, K.-Y. (2012), "Franchisor-Franchisee Supply Chain Cooperation: Sharing Of Demand Forecast Information in High-Tech Industries", Industrial Marketing Management, 41, 1164-1173.

YILDIRIM, A., ŞİMŞEK, H. (2008), Sosyal Bilimlerde Nitel Araştırma Yöntemleri, 7. Baskı, Tıpkı Basım, Seçkin Yayıncılık, Ankara.

YIN, R.K. (2002), Case Study Research (Design and Methods), Sage Publication, USA.

UFRAD Franchising Derneği, http://www.ufrad.org.tr/tr/10sorudafranchise.asp (29.11.2015). 